\title{
Legal Perspectives on Drug Trafficking
}

\author{
Amber Marks
}

\section{Introduction}

There is, or at least has until very recently been, a global consensus that drug trafficking is a heinous crime deserving of severe punishment, coupled with a widespread yet largely unexplored disagreement on what conduct this does or should consist of. At first glance it might seem odd that the legal parameters of such an important crime as drug trafficking should be ambiguous. In everyday usage drug trafficking might be easily and readily understood as having the same definition as 'trafficking' in the Oxford English Dictionary (trading in something illegal) and for that something traded in to be drugs. The etymology of the word 'trafficking' denotes commercial transportation of merchandise, thereby further implying its transnational nature. However, the 1988 Convention on Trafficking requires states to prohibit the possession, purchase, or cultivation of narcotic drugs or psychotropic substances for personal consumption, the inclusion of which suggests 'an extremely elastic definition of "trafficking". .'

Scientific and technological advances provide an important backdrop to our discussion on account of the challenge posed to the transnationality ${ }^{2}$ of drug trafficking by the emergence of large-scale domestic production, ${ }^{3}$ in countries once considered to be 'consumer states' ${ }^{4}$. However, it is the growing legal tensions ${ }^{5}$ within the international drug control system which are putting the hitherto consensual position in regard to the prohibition on drugs supply and their use for anything other than medical and scientific use (the Vienna consensus) under strain. They provide the essential backdrop. Significant legal and policy reforms at the national level have taken place in several jurisdictions in recent years that pose considerable challenges to the international legal framework for drug control, and beg important questions regarding states parties' international legal obligations. ${ }^{6}$ Recent tensions are signified by a 'renewed interest in the object and purpose of the system'. ${ }^{7}$

\footnotetext{
${ }^{1}$ Richard Vogler and Shahrzad Fouladvand, 'Part II UN Core Conventions on Transnational Organised Crime, The Convention against Illicit Traffic in Narcotic Drugs and Psychotropic Substances 1988 and the Global War on Drugs' in Pierre Hauck and Sven Peterke (eds), International Law and Transnational Organised Crime (OUP 2016).

2 See definition of 'transnational crime' in Article 3(2) of the United Nations Convention against Transnational Organized Crime: 'For the purpose of paragraph 1 of this article, an offence is transnational in nature if: (a) It is committed in more than one State; (b) It is committed in one State but a substantial part of its preparation, planning, direction or control takes place in another State; (c) It is committed in one State but involves an organized criminal group that engages in criminal activities in more than one State; or (d) It is committed in one State but has substantial effects in another State.'

${ }^{3}$ Particularly in relation to cannabis and new psychoactive substances, see: Rudi Fortson, Misuse of Drugs and Drug Trafficking Offences (Sweet and Maxwell, $6^{\text {th }}$ edition, 2011) 89; Tom Decorte and Gary R Potter, 'The globalisation of cannabis cultivation: A growing challenge' (2015) 26 International Journal of Drug Policy 221-225. It should be noted that the emergence of domestic production is often attributed to drug prohibition: see for example Bernd Werse, 'Legal issues for German-speaking cannabis growers. Results from an online survey' (2016) 28 International Journal of Drug Policy 113-119.

${ }^{4}$ Neil Boister, Penal Aspects of the UN Drug Conventions (Kluwer Law International 2001) 45; 124.

${ }^{5}$ Neil Boister, 'Waltzing on the Vienna Consensus on Drug Control? Tensions in the International System for the Control of Drugs' (2016) 29 Leiden Journal of International Law 389-409.

6 'International Law and Drug Policy Reform: Report of a Global Drug Policy Observatory (GDPO), International Centre on Human Rights and Drug Policy (ICHRDP), Transnational Institute (TNI) and Washington Office on Latin America (WOLA) Expert Seminar, Washington, D.C. 17-18 October 2014', available at <https://www.swansea.ac.uk/media/Expert\%20Seminar\%20Report\%20\%20International\%20Law\%20\&\%20Drug\%20Policy\%20Reform.pdf> accessed 28 Feb. 2017).

${ }^{7}$ Boister, 'Waltzing on the Vienna Consensus on Drug Control?' (n 5) 391.
} 
The aim of this chapter is to identify definitional disagreements and concordances regarding the notion of drug trafficking and to explore their source and implications. Definitions are important because how the problem of drug trafficking is defined goes a long way toward determining how laws are framed, how investigations and prosecutions are conducted, how mutual legal assistance across national borders is carried out and because financial transactions between different states and national jurisdictions can easily trigger legal conflicts with anti-money laundering legislation where definitional disagreements persist. ${ }^{8}$

\section{The international drug control regime}

Over the first half of the twentieth century, there were seven different instruments focusing on the control of the international trade of substances with a regulatory regime to ensure availability of substances for medical and scientific purposes while preventing their trade for other purposes. Notably, none of the controlled substances was prohibited and the legislation regarding domestic use or cultivation was left to the discretion of nation states. ${ }^{9}$ This regime can be contrasted with the drug control conventions that were opened for signature between 1961 and 1988, which were 'unprecedented in their scope and represented extraordinary international interventions in the domestic affairs of states'. ${ }^{10}$

The 1961 Single Convention on Narcotic Drugs (the 'Single Convention') ${ }^{11}$ - which sought to combine all of the previous drug treaties into one - strictly limited the use and trade in psychoactive drugs to medical and scientific purposes, and required that traditional uses of coca, opium and cannabis be abolished. The 1961 Single Convention (as amended by the 1972 Protocol) and the 1971 Convention were largely successful in their original goal of controlling the licit market and preventing the diversion of controlled substances for illicit purposes. However, illicit demand for psychoactive drugs started to increase (especially in the West), resulting in the expansion of illicit production and trafficking. Especially with regard to traditional plantbased drugs - cannabis, cocaine, and heroin - the markets became almost entirely illicit; cultivation, processing, international trade and street sales all turned into illegal business. ${ }^{12}$ One suggested explanation for the global failure to extinguish the supply of illicit drugs is that such efforts constitute an 'attempt to control the lives of individuals, whereas licit regulation has succeeded because it depends upon influencing the conduct of government administrations, professionals and private enterprise' ${ }^{13}$ The Single Convention (Schedule I and IV) and the 1971 Convention (Schedule I) prohibit most activities for non-medical and nonscientific purposes without specifying the means by which this should be accomplished. ${ }^{14}$ To suppress the illicit trade, member states adopted the 1988 Convention Against Illicit Traffic in Narcotic Drugs and Psychotropic Substances ${ }^{15}$ which further extended control over individuals by requiring parties to treat a wide range of drug offences (including possession for personal consumption) as criminal offences. At the same time, the exemption period for phasing out traditional uses of cannabis (1979) and opium and the coca

\footnotetext{
8 James O Finckenauer 'Problems of Definition: What is Organized Crime?' (2005) 8(3) Trends in Organized Crime 63.

${ }^{9}$ SK Chatterjee, Legal Aspects of International Drug Control (Martinus Nijhoff Publishers 1981).

${ }^{10}$ Vogler and Fouladvand (n 1) and see Robin Room 'Reform by subtraction: the path of denunciation of international drug treaties and reaccession with reservations' (2012) 23(5) International Journal of Drug Policy 401,401

11 The Single Convention on Narcotic Drugs (1961), subsequently amended by The 1972 Protocol Amending the Single Convention.

12 GDPO et al (n 6).

${ }^{13}$ Boister, Penal Aspects of the UN Drug Conventions (n 4) 124. On this point Boister cites Kettil Bruun, Lynn Pan, Ingemar Rexed, The Gentlemen's Club: International Control of Drugs and Alcohol (University of Chicago Press 1975) 276-277.

${ }^{14}$ Article 4 of the Single Convention limits the 'production, manufacture, export, import, distribution of, trade in, use and possession of drugs' to medical and scientific purposes. Articles 5 and 7 of the 1971 Convention prohibit all 'use' of Schedule I drugs except for scientific and 'very limited' medical purposes.

${ }^{15}$ Convention Against Illicit Traffic in Narcotic Drugs and Psychotropic Substances (1988).
} 
leaf (1989) expired. Under the Conventions, states parties must treat drug trafficking and related conduct as serious crimes.

The definition of the term 'illicit traffic' caused major difficulties in the negotiation of 1988 Convention. The principal source of disagreement was identified at the time as being between one group of delegations which 'strongly favoured a broad-based definition covering all aspects of the drug problem from production and supply to demand' and another which 'preferred a technical definition to a generic one and had argued that it was premature to make consumption the subject of international action'. ${ }^{16}$ The functional role played by the international drug conventions in the twentieth century, both in terms of establishing a nascent regime of global governance and legitimisation for police, military and a wide range of agencies, meant that 'the need to eradicate drug trafficking became a "taken for granted" universal knowledge that could never be questioned'. ${ }^{17}$ This may explain the emergence of a global consensus on the constitution of drug trafficking as a transnational crime in spite of the difficulties encountered in settling its legal parameters with any degree of precision. The compromise or 'general consensus' reached was that the notion of illicit trafficking would, instead of being defined, consist of a reference to all drug offences that states would be obliged to create and for this to include the possession, purchase or cultivation of a drug for personal consumption, but for the obligation in relation to these offences to be subject to the 'safeguard wording' that subjected this obligation to the constitution and basic principles of each signatory's legal system, and further provision was made for alternatives to imprisonment as a punishment for such offences when they are created. ${ }^{18}$

The possession, purchase or cultivation of narcotic drugs or psychotropic substances for personal consumption are listed in Article 3(2) of the 1988 Convention, thereby singling out this conduct and subjecting the obligation to criminalise it to the constitutional principles and the basic concepts of a state's legal system. Confusingly, cultivation is also included amongst the activities listed in Article $3(1){ }^{19}$ which are not subject to the safeguard wording. ${ }^{20}$ Some researchers have suggested that the references to 'cultivation' in Article 3(1) and the earlier references to this term in the Single Convention (1961) are to 'large-scale licensed cultivation', that is industrial and commercial cultivation as opposed to cultivation for 'gratuitous or non-profit supply ${ }^{21}$ and this would explain how it could be listed in Article 3(1) and yet be subject to the safeguard wording in Article 3(2) where its purpose is for personal consumption. The interpretation nevertheless remains ambiguous.

The general consensus reached was a political fudge which succeeded in obscuring underlying tensions. This obfuscation has been deepened by the enforcement and sentencing practices of several states that do not punish possession, purchase and cultivation for personal consumption but do retain criminal offences for

\footnotetext{
16 'United Nations Conference for the Adoption of a Convention against Illicit Traffic in Narcotic Drugs and Psychotropic Substances, Vienna, 25 November-20 December 1988: official records. Volume 2, Summary records of plenary meetings, summary records of meeting of Committee I and Committee II' (hereafter UN Conference 1988), Committee $1,24^{\text {th }}$ meeting, 151, para 13.

${ }^{17}$ Vogler and Fouladvand (n 1).

18 UN Conference 1988, Committee 1, 24 $4^{\text {th }}$ meeting, 151, para 13.

${ }^{19}$ The Convention against Illicit Traffic in Narcotic Drugs and Psychotropic Substances 1988 Article 3(1) (a) (ii): 'The cultivation of opium poppy, coca bush or cannabis plant for the purpose of the production of narcotic drugs contrary to the provisions of the 1961 Convention and the 1961 Convention as amended'.

${ }^{20}$ Although possession and purchase of drugs is also included in Article 3(1), this is limited to where the purpose of such conduct is any of the activities enumerated in Article 3(1)(i), i.e. 'the production, manufacture, extraction; preparation, offering, offering for sale, distribution, sale, delivery on any terms whatsoever, brokerage, dispatch, dispatch in transit, transport, importation or exportation of any narcotic drug or any psychotropic substance contrary to the provisions of the 1961 Convention, the 1961 Convention as amended or the 1971 Convention'.

${ }^{21}$ Kevin Dawkins, 'International Law and Legalising Cannabis' (1997) New Zealand Law Journal 281-284.
} 
this conduct in their criminal law. ${ }^{22}$ This was facilitated by the inclusion of the 'escape clause' 23 in relation to the possession, purchase or cultivation of a drug for personal consumption in Article 3(4)(d). The provision permits parties to apply any of a range of measures in the alternative to conviction or punishment, thereby providing an escape route from violation of the Convention's obligation in Article 3(2) to those Parties that criminalise and then choose as a matter of administrative policy not to prosecute or punish. ${ }^{24}$

There are thus three different groups of state parties to the 1988 Convention depending on their chosen means of conforming with the obligations in Article 3(2): (i) states in which acts for personal consumption do not constitute criminal offences on account of the 'safeguard wording'; (ii) states in which such acts constitute criminal offences but are not prosecuted or punished in accordance with the 'escape clause'; and (iii) states in which such conduct constitutes a criminal offence and is punished accordingly. A vexed question is the extent to which personal consumption can appropriately be termed 'drug trafficking' in states falling into (i) and (ii) above. The issue is further complicated by the ambiguity of the term 'personal consumption' which is nowhere defined in the international treaties.

\section{Attempts at Harmonisation in European Law}

Several calls have been made for refinement of the concept of drug trafficking within the European Union by both governmental and non-governmental bodies. ${ }^{25}$ The first attempt to harmonise the European conception of drug trafficking was made by the European Commission in 2001 in its proposal for a Council framework decision laying down minimum provisions on the constituent elements of criminal acts and penalties in the field of illicit drug trafficking. ${ }^{26}$ By way of preparation for this initiative the Commission carried out a study of the definitions used and penalties applied in the field of drug trafficking. ${ }^{27}$ This study showed that no national legislation includes a legal definition of illicit drug trafficking as a particular offence: the main punishable offences included in the national legislations are the production, cultivation, extraction, fabrication, acquisition, possession, importation, exportation, transport, sale, offer to sell, and the illegal transfer of ownership of drugs. It also revealed that there is a significant difference between the national legislation and its application in practice: in the majority of Member States, a drug user who sells drugs is in principle considered in the law as much a drug trafficker as any other drug seller. However, in practice, in all Member States a drug user is less severely punished if the sales are to finance their own consumption.

In Article 1 of the Commission's proposal, 'illicit drug trafficking' was defined as 'the act, without authorisation, of selling and marketing as well as, for profit, of cultivating, producing, manufacturing, importing or sending or, for the purpose of transferring for profit, of receiving, acquiring and possessing drugs' (author's emphasis). ${ }^{28}$ Article 2 of the proposal requires Member States to make illicit drug trafficking,

\footnotetext{
${ }^{22}$ European Commission, Directorate-General for Justice and Home Affairs, Study on the Legislation and Regulations on Drug Trafficking in the European Member States (February 2001); Niamh Eastwood, Edward Fox and Ari Rosmarin, $A$ Quiet Revolution: Drug Decriminalisation Policies in Practice across the Globe (Release 2016).

${ }^{23}$ Boister, Penal Aspects of the UN Drug Conventions (n 4) 129.

${ }^{24}$ Article 3.4(d): 'The Parties may provide, either as an alternative to conviction or punishment, or in addition to conviction or punishment of an offence established in accordance with paragraph 2 of this article, measures for the treatment, education, aftercare, rehabilitation or social reintegration of the offender.'

25 'Commission Staff Working Document: Impact Assessment Accompanying the document: Proposal for a Regulation of the European Parliament and of the Council on new psychoactive substances and proposal for a Directive of the European Parliament and of the Council amending Council Framework Decision 2004/757/JHA of 25 October 2004 laying down minimum provisions on the constituent elements of criminal acts and penalties in the field of illicit trafficking, as regards the definition of drug', Brussels, 17 Sept. 2013, SWD(2013) 319, 85 <http://eur-

lex.europa.eu/legal-content/en/ALL/?uri=CELEX:52013SC0319> accessed 28 February 2017.

26 'Proposal for a Council Framework Decision laying down Minimum Provisions on the Constituent Elements of Criminal Acts and Penalties in the Field of Illicit Drug Trafficking, submitted by the Commission on 27 June 2001 (2001/C 304 E/03)' (hereafter 2001 Council Proposal), Official Journal of the European Communities 304 E/172, 30 October 2001.

${ }^{27}$ European Commission, Directorate-General for Justice and Home Affairs (n 22).

${ }^{28} 2001$ Council Proposal (n 26).
} 
as defined in Article 1 of the proposal, a criminal offence. The Commission underlined that it proposed a common definition, covering acts which are classified as offences in all Member States, and that essential criteria in this definition are the notions of acting 'for profit' and 'without authorisation'. ${ }^{29}$ The definition proposed by the Commission specifically excluded (i) simple users who illegally produce, acquire and/or possess narcotics for personal use and (ii) users who sell narcotics without the intention of making a profit (for example, someone who passes on narcotics to their friends without making a profit), which is 'in line with the practice in all the Member States'. The principal target of the proposed definition was 'transnational trafficking and actions undertaken for the purpose of transferring ownership for profit'. ${ }^{30}$

According to the Commission, this proposed definition of drug trafficking embraced 'the key elements' of trafficking in the 1988 United Nations Convention against illicit traffic in narcotic drugs and psychotropic substances..$^{31}$ In drafting the proposed definition the Commission also took into account the national provisions defining the offences connected with illicit drug trafficking, which were analysed as part of the study on the definitions, sanctions and practical implementation of the legislation on illicit drug trafficking in the Member States, carried out by the Commission prior to proposing its Framework Decision. ${ }^{32}$

It took the Council of the European Union over two years to resolve disagreements and finalise a text which then took Parliament a further seven months of discussions to agree upon. The result was that the whole text as proposed by the Commission was changed. The Commission wanted to propose 'stricter definitions than those laid down in the UN Conventions on the fight against drugs, but the Council reduced the definition to those in the conventions'.$^{33}$ In the ensuing Council Framework Decision 2004/757/JHA, ${ }^{34}$ we find a similar compromise to that reached in the 1988 Convention. The Council Framework Decision does not include a definition of drug trafficking, but instead lists the conduct Member States are obliged to make punishable in Article 2 and under the heading of 'crimes linked to trafficking in drugs and precursors'. That the final text constituted a political compromise is clear from the Explanatory Statement in the Report of the Committee on Citizens' Freedoms and Rights, Justice and Home Affairs, European Parliament in February 2004 , which concluded that on account of the length of time it took Parliament to reach unanimous agreement it was 'politically wiser to accept the framework decision as agreed' than for further amendments to be tabled, bearing in mind that it is a 'first small but very decisive step towards the creation of a common judicial space' and that 'it is clear that this framework decision does not ask Member States to change their drug policy'.

Article 2(1) of Council Framework Decision 2004/757/JHA provides that 'Each Member State Shall take the necessary measures to ensure that the following intentional conduct when committed without right is punishable: a) ... the offering, offering for sale, distribution, sale, delivery on any terms whatsoever, brokerage, dispatch in transit, transport, importation or exportation of drugs; ... c) the possession or purchase of drugs with a view to conducting one of the activities listed in (a); d) the ... transport or distribution of precursors, knowing that they are to be used in or for the illicit production or manufacture of drugs'. Article 2(2) specifically excludes from the scope of the Framework Decision conduct described in

\footnotetext{
${ }^{29}$ Council Proposal (n 26), Explanatory Memorandum, Commentary on Individual Articles.

$30 \mathrm{Ibid}$

$31 \mathrm{lbid}$

32 Ibid.

${ }^{33}$ Report on the proposal for a Council Framework Decision laying down minimum provisions on the constituent elements of criminal acts and penalties in the field of drug trafficking (15102/2/2003 - C5-0618/2003 2001/0114(CNS)) (Renewed consultation) Committee on Citizens' Freedoms and Rights, Justice and Home Affairs, European Parliament, 23 Feb. 2004, 6. Available at http://www.europarl.europa.eu/sides/getDoc.do?pubRef=//EP//TEXT+REPORT+A5-2004-0095+0+DOC+XML+V0//EN\&language=pl

${ }^{34}$ Council Framework Decision 2004/757/JHA of 25 October 2004 laying down minimum provisions on the constituent elements of criminal acts and penalties in the field of illicit drug trafficking, Official Journal of the European Union, $\mathrm{L}$ $335 / 8,11.11 .2004$.
} 
paragraph (1) 'when it is committed by its perpetrators exclusively for their own personal consumption as defined by national law'. ${ }^{35}$

The vagueness surrounding the definition of 'personal consumption' was criticised in a minority opinion by members of the Committee on Citizens' Freedoms and Rights, Justice and Home Affairs of the European Parliament. It was noted that under the Framework Decision minor drug law offences that are indirectly linked to personal consumption - such as passing a joint to a friend - are assimilated to 'drug trafficking' ${ }^{36}$ Such conduct would have been specifically excluded under the Commission's original proposal, which included the requirement of acting 'for profit'.

\section{Discussion}

The two terms 'trafficking' and 'personal consumption' provide the conceptual framework for the international drug control regime. Neither term is legally defined. The principal disagreement behind the 1988 consensus was the extent to which conduct related to 'personal consumption' should fall within the scope of 'drug trafficking'. This consensus left the scope of drug trafficking ambiguous and 'elastic', providing states with the freedom to abstain from criminalising acts for personal consumption where to do so would conflict with their constitution or the basic principles of their legal system, and the freedom to abstain from punishing such conduct where it is criminalised. In several national jurisdictions one or other of these two key terms is defined in contradiction to the other (i.e. it is present wherever the other is not). In Spain, for example, where cultivation and possession for personal consumption is not a criminal offence on account of the 'safeguard wording', ${ }^{37}$ there will be no criminal offence in the absence of trafficking (tráfico), which is said to take place where the supply is for 'third parties' on account of the latter amounting to an injury to public health as opposed to individual health. Who and what circumstances characterise a supply to 'third parties' is mired in controversy and the Spanish Supreme Court's case-law on the scope of the drug trafficking offence has been described as inconsistent and contradictory. ${ }^{38}$ In contrast, the law in many countries provides that there will be trafficking wherever the definition for personal consumption is unsatisfied; the offence of trafficking is committed where the amount possessed exceeds that stipulated by the law in quantitative thresholds for 'personal consumption'. The amounts stipulated by such thresholds are widely criticised on account of their apparent arbitrariness. ${ }^{39}$

Attempts at harmonisation regarding the notion of drug trafficking within the European Union underline a deeper ambiguity regarding the scope of the term 'personal consumption' itself, which is evident both within and beyond the European Union. In the law and/or practice of some jurisdictions, the notion of 'social supply' is clearly treated as belonging outside the scope of drug trafficking. In Spain and Chile the concept of personal consumption is not narrowly confined to that of one individual: in Spain it includes closed circles of drug users known to each other, and in both Spain and Chile a cannabis plant can be cultivated on behalf of several people for their collective consumption. ${ }^{40}$ In its proposal (2001) the Commission proposed to exclude from the scope of the Framework Decision on illicit drug trafficking 'simple users who illegally produce, acquire and/or possess narcotics for personal use and (ii) users who sell narcotics without the intention of making a profit (for example, someone who passes on narcotics to their friends without making a profit)'.

\footnotetext{
35 Ibid (author's emphasis).

${ }^{36}$ Ibid, Minority Opinion by Maurizio Turco, Marco Cappato and Ilka Shröder, 9.

${ }^{37}$ Boletín Oficial de las Cortes Generales, Congreso de los Diputados, núm 219, 8 October 1992, 10772-10774

<http://www.congreso.es/public_oficiales/L4/CONG/DS/PL/PL_219.pdf> accessed 2 August 2016; and núm 227, 12 November 1992, 11263 <http://www.congreso.es/public_oficiales/L4/CONG/DS/PL/PL_227.PDF> accessed 14 October 2016.

38 Jacobo Dopico Gómez-Aller, Transmisiones atípicas de drogas: Crítica a la jurisprudencia de la exceptionalidad (Tirant lo Blanch 2012).

${ }^{39}$ Niamh Eastwood, Edward Fox and Ari Rosmarin, A Quiet Revolution: Drug Decriminalisation Policies in Practice across the Globe (Release 2016).

40 Ministerio Publico C/ Paulina Patricia Gonzàlez Cespedes R.U.C. № 1.300.243.332-4 R.I.T. № 14-2015.
} 
The Commission thereby proposed to exclude what might be categorised as social supply. In the UK literature Gary Potter has discussed the evidential problems with social supply "as a legal concept" at some length and similar problems plague the jurisprudence of Spain's Supreme Court: ${ }^{41}$

Concepts of relationship (including but by no means exclusively friendship) and (although to a lesser extent) profit have been shown to be subjective; such subjectivity does not sit easily with legal clarity. There may be a clear distinction between extremes in that drug supply from a family member or a long-term friend may be clearly different from buying off a stranger in an open market, but there is a lot of grey area in between. How do we provide evidence as to whether somebody is a stranger, or a friend? When does a stranger become a friend? Does the fact that a drug supplier is a friend of the user actually have any bearing on the supplier's status as a dealer? Similarly for the commercial aspect of social supply there are obvious extremes - a genuine gift against trafficker recording vast profits but again much grey area between. How much 'profit' is profit? ${ }^{42}$

The approach to social supply in Spain is different to that theorized in the UK literature because its roots are in distinguishing between self-harm (not criminal) and harm to public health (criminal). ${ }^{43}$ Nonetheless both approaches are clearly concerned with restricting the full impact of the criminal law for 'real dealers' by distinguishing between 'professional traffickers' ${ }^{\prime 44}$ or 'dealing proper' ${ }^{45}$ and personal use or social supply/shared consumption. The concept of social supply that emerged in Spain was developed in the jurisprudence of Spain's Supreme Court so as to limit the otherwise disproportionate reach of the criminal law. ${ }^{46}$ In the UK the concept of 'social supply' emerged in legal theory and sentencing practice from the 'noble aim' of shaping the laws so as to enable this form of drug distribution to be distinguished from 'real dealing' ${ }^{47}$ The purpose of the distinction is to ensure that social supply is punished less severely (and in some jurisdictions, not at all). An independent inquiry into the Misuse of Drugs Act (Police Foundation, $2000)^{48}$ called for the creation of an offence of 'dealing' to differentiate it from social supply. In response, Hough et al proposed that social supply be defined as 'the non-commercial (or non-profit making) distribution of cannabis to non-strangers' (author's emphasis).$^{49}$ Although the UK government committee rejected the recommendation of the Police Foundation that those engaged in social supply escape prosecution on the basis that it was 'a crime which must be punished' it acknowledged that this form of distribution (supply to friends for their personal consumption) is on 'a different scale from commercial supply'. ${ }^{50}$

In light of the difficulties which plague attempts to distinguish drug trafficking from personal consumption and social supply within the international or European drug control regime, another framework may be

\footnotetext{
${ }^{41}$ Amber Marks, 'Defining “Personal Consumption” in Drug Legislation and Spanish Cannabis Clubs' 68(1) International \& Comparative Law Quarterly (2019).

42 Gary Potter, 'Exploring retail-level drug distribution: Social supply, "real” dealers and the user/dealer interface' in Zsolt Demetrovics, Jane Fountain, Ludwig Kraus (eds), Old and New Policies, Theories, Research Methods and Drug Users Across Europe (PABST Science Publishers 2009) 67.

43 Marks, "Treating the "personal" as private' (n 41).

${ }^{44}$ European Committee on Crime Problems, Council of Europe Penal Aspects of Drug Abuse (Strasbourg, 1974$) 97$.

${ }^{45}$ Leah Moyle, Ross Coomber and Jason Lowther, 'Crushing a Walnut with a Sledge Hammer? Analysing the Penal Response to the Social Supply of Illicit Drugs', Social and Legal Studies 22.4 (2013) 553-573 at 569.

${ }^{46}$ Amber Marks, [Evidence for the Parliament of Catalunya in Relation to the legislative intiative for a Law on Associations of Cannabis Consumers] 'Aportaciones por Escrito con Relación a la Proposicion de Ley de las Asosiciones de Personas Consumidoras de Cannabis', 30 Nov. 2016, available at

http://www.parlament.cat/document/intrade/181920 (accessed 28 Feb. 2017).

${ }^{47}$ Potter (n 42) 71.

${ }^{48}$ The Police Foundation, Report of the Independent Inquiry into the Misuse of Drugs Act 1971 (London, 2000).

49 Mike Hough et al, 'A Growing Market: The Domestic Cultivation of Cannabis' (Joseph Rowntree Foundation, 2003 ) 36.

50 Select Committee on Home Affairs, Third Report (Session 2001-2002) 'The Government's Drug Policy: Is it Working? col 82 <https://www.publications.parliament.uk/pa/cm200102/cmselect/cmhaff/318/31806.htm\#a20> accessed 20 March 2017.
} 
required for progress to be made in this regard. The role of the international human rights framework in providing 'a readily available and legally binding set of broad indicators' against which drug policy goals can be assessed has already been identified..$^{51}$ The European Union Drugs Strategy (2013-2020) ${ }^{52}$ is avowedly based 'first and foremost on the fundamental principles of EU law and, in every regard, upholds the founding values of the Union: respect for human dignity, liberty, democracy, equality, solidarity, the rule of law and human rights'. The Strategy is also avowedly based on international law and in its clarification of what international law means in this context the preface to the Strategy makes reference to the relevant UN conventions ${ }^{53}$ and to the Universal Declaration on Human Rights.

Whilst the application of human rights law to the recreational use of drugs remains controversial ${ }^{54}$ and there is still much to be resolved in the application of human rights law to recreational drug use (and in particular the lack of rigour regarding the application in the drugs field of the proportionality principle that requires any interference with rights to be a minimally intrusive means of achieving a legitimate aim $)^{55}$ the foundations for its application are apparent in comparative human rights law and there is a growing body of law emerging which recognises recreational drug use as coming within the constitutionally protected realms of privacy, autonomy and free assembly, guarantees which 'uphold the dignity of the individual and protect his right to develop in accordance with the inward forces which make him a unique human being'. ${ }^{56}$ The earliest articulation in comparative law of the constitutional protection of cannabis consumption for recreational purposes appears in a 1972 decision by the Supreme Court of Hawaii ${ }^{57}$ and the most recent in 2015 in the Supreme Courts of Mexic ${ }^{58}$ and Chile ${ }^{59}$, with similar decisions in Argentina ${ }^{60}$ and Colombia in the preceding decade.$^{61}$ In Europe similar decisions have been reached in lower courts in Germany ${ }^{62}$ and

${ }^{51}$ Damon Barrett, 'Harm Reduction is not enough for supply side policy: A human rights-based approach offers more' (2012) 23 International Journal of Drug Policy 16, 19. See also Damon Barrett and Manfred Nowak, 'The United Nations and Drug Policy: Towards a human rights-based approach' in Aristotle Constantinides and Nikos Zaikos (eds), The Diversity of International Law. Essays in Honour of Professor Kalliopi K. Koufa (Brill/Martinus Nijhoff 2009) 449-477.

${ }^{52}$ Council of the European Union, 'EU Drugs Strategy' 17547/12 adopted by the Council on 7 December 2012 <http://register.consilium.europa.eu/doc/srv?l=EN\&f=ST\%2017547\%202012\%20INIT> accessed 20 March 2017.

${ }^{53}$ The UN Single Convention on Narcotic Drugs of 1961 as amended by the 1972 Protocol, the Convention on Psychotropic Substances (1971) and the Convention against the Illicit Traffic in Narcotic Drugs and Psychotropic Substances (1988).

${ }^{54}$ See e.g. Saul Takahashi, Human Rights and Drug Control: The False Dichotomy (Bloomsbury 2016): Kindle edition 4623-7: 'In sum, there is no foundation for any so-called "right to abuse drugs". There is nothing in international human rights law that points to such a right, and the only justifications that advocates of drug liberalisation are able to muster on this point consist of classical liberal philosophy from the 19th century, and concepts specific to bourgeois Western culture. Such justifications ring somewhat hollow in the ears of most people in the world, and are extremely weak grounds on which to stand for organisations or individuals promoting modern international human rights standards.' ${ }^{55}$ Damon Barrett, 'Security, development and human rights: Normative, legal and policy challenges for the international drug control system' (2010) 21 International Journal of Drug Policy 140, 142.

${ }^{56}$ State v Kanter 493 F.2d 306 (1972) 314.

${ }^{57}$ Ibid

${ }^{58}$ The citation for the Mexican judgement is $237 / 2014$ but references will be made to the English translation which is available at https://www.scribd.com/doc/289159427/Mexico-s-Supreme-Court-Ruling-on-Cannabis-English-Translation. ${ }^{59}$ Rol 4949-2015 decided on 4 June 2015 <https://drive.google.com/file/d/OBweld7nyNPvhNW90aDVnMERPTUU/view> accessed 2 August 2016.

${ }^{60} \mathrm{D}$ Cozac, 'Rulings in Argentinian and Colombian courts decriminalize possession of small amounts of narcotics' (2009) 14(2) HIV/Aids Policy \& Law Review 2009 cited in Eastwood, Fox and Rosmarin (n 22) 13.

${ }^{61}$ Sentence No C-221/94, Constitutional Court Gazette 1994 Special Edition (available at www.drugtext.org/legal), cited in Boister, Penal Aspects of the UN Drug Conventions (n 4) 125, fn 228.

${ }^{62}$ In Germany, criminalisation of cannabis under the Narcotics Act was considered unconstitutional by the Regional Court in Lübeck on the basis that as intoxicants, such as alcohol, were not criminalised, it violated the principle of equality (article 3(1) of the Basic Law) and because becoming intoxicated fell within the principle of self-determination (article 2(1) of the Basic Law): BverfG NJW 1994, 1577 (available at www.drugext.org/legal) as cited in Boister, Penal Aspects of the UN Drug Conventions (n 4) 125, fn 228. 
several decisions by the Constitutional Court of Italy. ${ }^{63}$ The United Kingdom appears to be the only jurisdiction in which the courts have specifically excluded recreational drug use from the ambit of privacy. ${ }^{64}$

\section{Conclusion}

The functional role played by the international drug conventions in the twentieth century, both in terms of establishing a nascent regime of global governance and legitimisation for police, military and other enforcement agencies, meant that 'the need to eradicate drug trafficking became a "taken for granted" universal knowledge that could never be questioned'. ${ }^{65}$ This may explain the emergence of a global consensus on the constitution of drug trafficking as a transnational crime in spite of the difficulties encountered in settling its legal parameters with any degree of precision. The desire to create a common judicial space on drug trafficking within the European Union resulted in a second political fudge on the legal definition of trafficking. The difficulties which have plagued attempts by the European Union to harmonise its notion of drug trafficking and to provide for stricter definitions of what it entailed have revealed the depth and extent of divergence but also the persistent prevalence of attempts to distinguish drug trafficking from activities related to personal consumption and social supply. On account of the failure of international and European efforts to clarify the legal parameters of the notion of drug trafficking, it is time to consider human rights law as providing a more robust and transparent legal framework for drug policy. ${ }^{66}$

\footnotetext{
63 Eastwood, Fox and Rosmarin (n 22).

${ }^{64} R v$ Morgan [2002] EWCA Crim 721: 'We consider that there is no arguable point by reference to Article 8 of the schedule to the Human Rights Act. The learned judge delivered a 32 page judgment in which he concluded that Article 8 was not engaged at all. A right to private life did not involve or include a right to self intoxication, nor the right to possession or cultivation of cannabis, whether for personal consumption within one's home or otherwise. He agreed with the decision of His Honour Judge Rivlin QC and held, echoing the language of the Human Rights authorities on the right to private life to which he had been referred, that a restriction or limitation of the right to take drugs in the privacy of one's home or elsewhere is not an intrusion into personal space. It is not an affront to personality. "Nor," he said, "Have I seen anything to suggest that that can sensibly be seen as a barrier against the development and fulfilment of a person's personality". We agree. A restriction to the possession, use or cultivation of drugs is not within the ambit or concern of Article 8 at all.'

${ }^{65}$ Vogler and Fouladvand (n 1).

${ }^{66}$ Marks, 'Defining "Personal Consumption” (n 41).
} 